CASE REPORT

\title{
Ankylosing Spondylitis: a Case Report
}

Gabriela CEOBANU' ', Gina GHEORGHE¹,2, Daniela OPRIS-BELINSKI ${ }^{2,3}$, Nicolae BACALBASA ${ }^{2,4}$, Ovidiu BRATU2,5, Camelia DIACONU1,2

\begin{abstract}
Introduction: Ankylosing spondylitis is a chronic inflammatory disorder which primarily affects the axial skeleton, the major characteristic of the disease being the early involvement of the sacroiliac joints. The condition manifests by chronic inflammatory back pain and, as the disease progresses, patients will develop extreme impairment of spinal mobility because of spinal fusion. Case presentation: A 66-year-old man, diagnosed with HLA-B27-positive ankylosing spondylitis, permanent atrial fibrillation, ischemic cardiac disease, arterial hypertension, type 2 diabetes mellitus and stage 3A chronic kidney disease, was admitted for cervicalgia radiated to both shoulders and bilateral mechanical gonalgia. His son was also diagnosed with ankylosing spondylitis at the age of 29 years. Regarding the history of ankylosing spondylitis treatment, initially, the patient was prescribed nonsteroidal antiinflammatory drugs (NSAIDs); because of the inadequate response to NSAIDs, biological therapy with an anti-TNF agent was initiated (Infliximab). Fifteen months after the initiation of Infliximab, the patient presented with worsening symptoms; anti-Infliximab antibodies were detected, therefore he was switched to another anti-TNF agent, Adalimumab. Upon current admission, the clinical examination revealed thoracic kyphosis and marked limitation of cervical and lumbar spine mobility. Blood tests revealed mild anemia, inflammatory syndrome and azotate retention. The pelvic X-ray showed grade 3-4 bilateral sacroiliitis. The continuation of treatment with Adalimumab and Sulfasalazine was decided, with close monitoring of the patient. Conclusions: Ankylosing spondylitis is a multisystem inflammatory disorder, whose natural course includes periods of flares and remission. The peculiarity of this case consists in the early development of anti-Infliximab antibodies (secondary non-responder).
\end{abstract}

Keywords: ankylosing spondylitis, HLA-B27, sacroiliitis.

\section{Rezumat}

Introducere: Spondilita anchilozantă reprezintă o boală cronică inflamatorie care afectează predominant coloana vertebrală, având drept caracteristică majoră afectarea precoce a articulațiilor sacroiliace. Spondilita anchilozantă se manifestă prin durere lombară cronică, cu caracter inflamator, iar pe măsură ce boala progresează, pacienții vor dezvolta limitare severă a mobilității coloanei vertebrale, din cauza fuziunii corpilor vertebrali. Prezentarea cazului: Un pacient de sex masculin, în vârstă de 66 de ani, diagnosticat cu spondilită anchilozantă HLA-B27 pozitivă, fibrilație atrială permanentă, boală cardiacă ischemică, hipertensiune arterială, diabet zaharat tip 2 și boală cronică de rinichi stadiul 3A, s-a internat pentru cervicalgie iradiată la nivelul ambilor umeri și gonalgie bilaterală cu caracter mecanic. În ceea ce privește antecedentele heredo-colaterale, fiul pacientului a fost de asemenea diagnosticat cu spondilită anchilozantă la vârsta de 29 de ani. Inițial, spondilita anchilozantă a fost tratată cu anti-inflamatoare non-

\footnotetext{
${ }^{1}$ Clinical Emergency Hospital of Bucharest, Bucharest, Romania

${ }^{2}$ "Carol Davila" University of Medicine and Pharmacy, Bucharest, Romania

${ }^{3}$ „Sf. Maria" Clinical Hospital, Bucharest, Romania

4 "Ion Cantacuzino" Clinical Hospital, Bucharest, Romania

${ }^{5}$ Emergency University Central Military Hospital, Academy of

Romanian Scientists, Bucharest, Romania
}

\section{Corresponding author.}

Camelia DIACONU, Clinical Emergency Hospital of Bucharest, Bucharest, Romania.

E-mail: drcameliadiaconu@gmail.com 
steroidiene (AINS); din cauza răspunsului inadecvat la AINS, a fost inițiată terapia biologică cu un agent anti-TNF (Infliximab). După 15 luni de la inițierea terapiei cu Infliximab, pacientul s-a prezentat la spital cu simptome agravate; au fost identificați anticorpi anti-Infliximab, motiv pentru care s-a realizat switch-ul pe un alt agent anti-TNF, și anume Adalimumab. La internarea actuală, examenul clinic osteo-articular a evidențiat cifoză toracală, precum și limitarea marcată a mobilității coloanei cervicale și lombare. Analizele de laborator au obiectivat anemie, sindrom inflamator și sindrom de retenție azotată. La radiografia de bazin s-a observat sacroileită bilaterală grad 3-4. S-a decis continuarea tratamentului cu Adalimumab și Sulfasalazină, cu monitorizarea atentă a pacientului. Concluzii: Spondilita anchilozantă este o boală inflamatorie multisistemică marcată de perioade de remisiune care alternează cu perioade de exacerbare. Particularitatea acestui caz constă în dezvoltarea precoce a anticorpilor anti-Infliximab.

Cuvinte cheie: spondilită anchilozantă, HLA-B27, sacroileită.

\section{INTRODUCTION}

Spondyloarthritis $(\mathrm{SpA})$ is a potentially disabling form of chronic inflammatory arthritis and has been classified as axial spondyloarthritis (axSpA) and peripheral $\mathrm{SpA}^{1}$. Ankylosing spondylitis (also named radiographic axial spondyloarthritis) represents a subtype of axial spondyloarthritis, characterized by significant abnormalities of affected sacroiliac joints at conventional radiography. Ankylosing spondylitis (AS) is an inflammatory rheumatic disease with a heterogeneous clinical presentation. The term 'ankylosing' is derived from the Greek word "ankylos”, which means stiffening of a joint, and "spondylos”, which means vertebra. The main symptom of the disease is chronic inflammatory back pain, accompanied by morning stiffness, which improves with exercise ${ }^{2}$. It is often associated with one or more articular lesions, including synovitis, enthesitis, and dactylitis, as well as extra-articular manifestations such as uveitis, psoriasis, inflammatory bowel disease, cardiovascular involvement ${ }^{3}$. The disease is more frequently encountered in men, the mean age of onset being between 20 and 30 years ${ }^{1}$.

The prevalence of ankylosing spondylitis has been clearly correlated with the human leukocyte antigen (HLA)-B27 positivity; in HLA-B27-positive patients, the prevalence of $\mathrm{AS}$ is estimated to be approx. $6 \%{ }^{4}$. The geographic distribution of AS parallels the distribution of HLA-B27, which varies among different ethnic communities. In a national survey conducted in the United States, in 2009, the prevalence rates of HLA-B27 in non-Hispanic whites, Mexican-Americans, and non-Hispanic Blacks were 7.5, 4.6, and 1.1 percent, respectively ${ }^{5}$. In a study conducted in Romania, published in 2010, the distribution of HLA-B27 in Romanian patients diagnosed with spondyloart- hritis was analysed ${ }^{6}$; in the AS group, the HLA-B27 frequency was $72.1 \%$, similar to that found in several regions in the Mediterranean area ${ }^{6}$ (Table 1 ).

Multiple etiological factors have been shown to be involved in AS: genetic background, immune reaction, microbial infection, endocrine factors ${ }^{4}$.

The critical role genetic factors play in the genesis of AS is already known ${ }^{7}$. Hereditary factors were first confirmed within families in a scientific paper published in 1961 by De Blecourt et $\mathrm{al}^{8}$. Twin studies have showed that there is a significantly higher similarity between monozygotic twins (63\%) than dizygotic twins (23\%). One of the most important genetic factors is major histocompatibility complex (MHC) class I allele HLA-B27; 90-95\% of AS patients are HLAB27 positive, while 1-2\% of HLA-B27-positive populations develop $\mathrm{AS}^{9}$. However, studies have shown that the overall contribution of HLA-B27 to AS heritability is only $20 \%$, thus suggesting that other genetic factors contribute to the genesis of $A S$, some of which are HLA-B7, HLA-B16, HLA-B35, HLA-B38, as well as several non-MHC nonsynonymous single nucleotide polymorphisms ${ }^{10}$.

$\mathrm{AS}$ is related to a number of autoimmune diseases, including inflammatory bowel disease, psoriasis and anterior uveitis, indicating that these diseases may share a common genetic basis and immunological processes with AS.

Microbial infection acts as a triggering factor for the host innate immune system and AS development. Placed in a germ-free environment, HLA-B27 transgenic rats failed to develop features of $\mathrm{SpA}$. This changed when commensal bacteria were introduced into the germ-free models, suggesting possible interactions between HLA-B27 and the microbiome ${ }^{11,12}$. 
Endocrine factors and vitamin D deficiency are other factors incriminated in AS genesis ${ }^{13,14}$.

\section{CASE PRESENTATION}

In February 2017, a 66-year-old male patient presented for cervicalgia radiating to the thoracic spine and both shoulders, associated with morning stiffness that lasted more than 2 hours, which improved with mobility or exercise, and bilateral mechanical gonalgia. The symptoms gradually intensified over the last 7 days. His past medical history included HLA-B27-positive ankylosing spondylitis (diagnosed in 1996), permanent atrial fibrillation treated with beta-blockers and oral anticoagulant, ischemic heart disease, chronic heart failure NYHA class II, arterial hypertension, type 2 diabetes mellitus and stage $3 \mathrm{~A}$ chronic kidney disease. The patient's son was diagnosed with ankylosing spondylitis at the age of 29 years.

In 1996, the patient presented low back inflammatory pain, alternating buttock pain and lumbosciatica; based on clinical and paraclinical investigations, the diagnosis of HLA-B27-positive ankylosing spondylitis was established. Treatment with Indomethacin (150 $\mathrm{mg} /$ day) and Sulfasalazine was initiated, interrupted after 3 months. In June 2014, the patient presented with important tumefaction of the knees and ankles and inflammatory syndrome (ESR $60 \mathrm{~mm} / \mathrm{h}$ and CRP 145.3 $\mathrm{mg} / \mathrm{L})$. Sulfasalazine, along with Diclofenac, were prescribed. In September 2014, the patient returned to the hospital with persistent tumefaction of both knees and ankles and still elevated serum levels of inflammatory markers (ESR $46 \mathrm{~mm} / \mathrm{h}, \mathrm{CRP} 26.7 \mathrm{mg} / \mathrm{L}$ ); treatment with Sulfasalazine and Infliximab $(5 \mathrm{mg} / \mathrm{kg}$ iv at 0,2 and 6 weeks, and then every $6-8$ weeks) was prescribed. In February 2015, the patient presented for reevaluation; the clinical examination, as well as laboratory tests (ESR $18 \mathrm{~mm} / \mathrm{h}$, CRP $2.6 \mathrm{mg} / \mathrm{L}$ ), showed an adequate response to Infliximab therapy.

In December 2015, the patient was hospitalized for another ankylosing spondylitis flare-up. High levels of inflammatory markers (ESR $20 \mathrm{~mm} / \mathrm{h}, \mathrm{CRP} 17.16$ $\mathrm{mg} / \mathrm{L}$ ) were noted and anti-Infliximab antibodies were detected, therefore the patient was switched to treatment with Adalimumab (40 mg subcutaneously every two weeks) and Sulfasalazine (500 $\mathrm{mg} \mathrm{x} 5 /$ day).

In October 2016, the patient presented for clinical and biological reevaluation. Inflammatory markers were within normal range (ESR $15 \mathrm{~mm} / \mathrm{h}$, CRP 3.07 $\mathrm{mg} / \mathrm{L})$.

Upon current admission, the osteo-articular examination revealed thoracic kyphosis, marked limitation of cervical and lumbar spine mobility and also restriction of the thoracic cavity expansion. The occiput-to-wall distance was $29 \mathrm{~cm}$, the tragus-acromion distance was $17 \mathrm{~cm}$, the chin-to-chest distance was $10 \mathrm{~cm}$, the finger-to-floor distance was $37 \mathrm{~cm}$, Schober $=1 \mathrm{~cm}$, chest expansion=1 cm (Figures 1-6). The electrocardiogram revealed atrial fibrillation with a heart rate of 70 beats/ min. The pelvic X-ray showed grade 3-4 bilateral sacroiliitis (Figure 7).

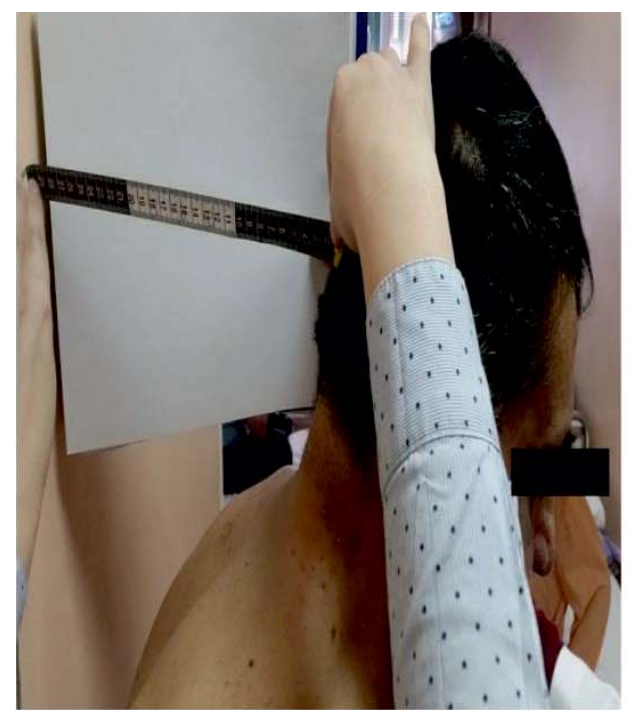

Figure 1. Occiput-to-wall distance.

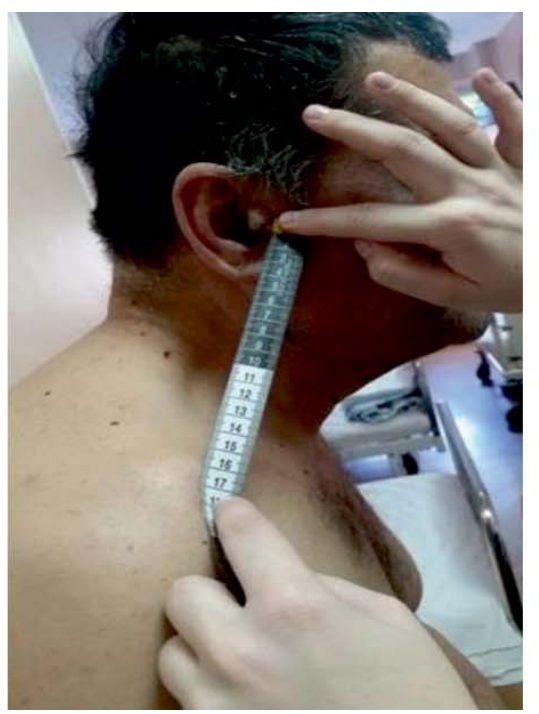

Figure 2. Tragus-acromion distance.

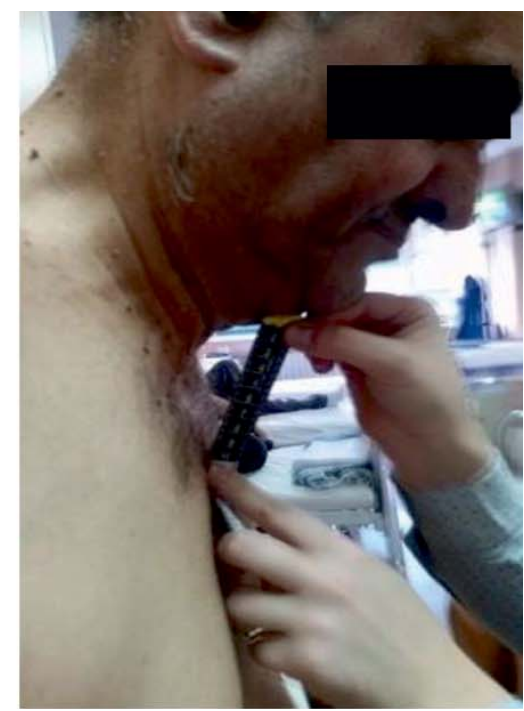

Figure 3. Chin-to-chest distance. 


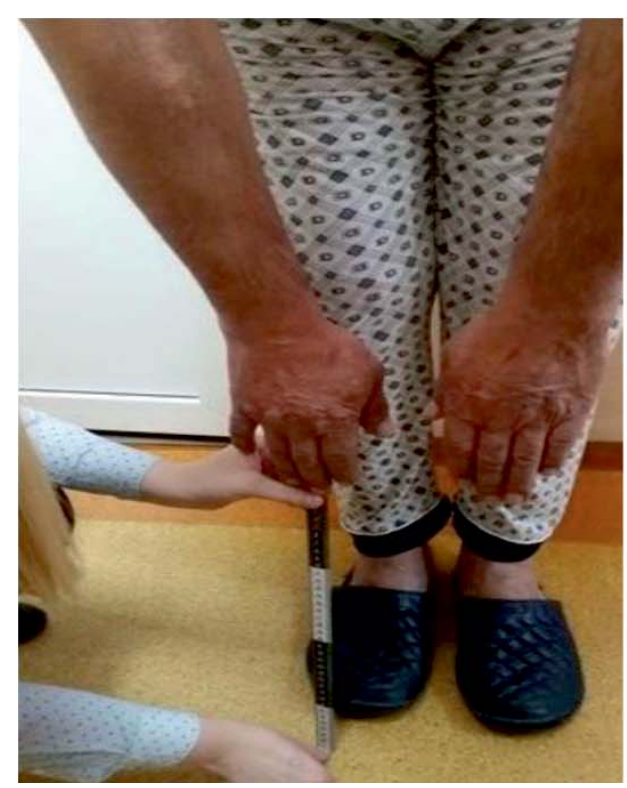

Figure 4. Finger-to-floor distance.

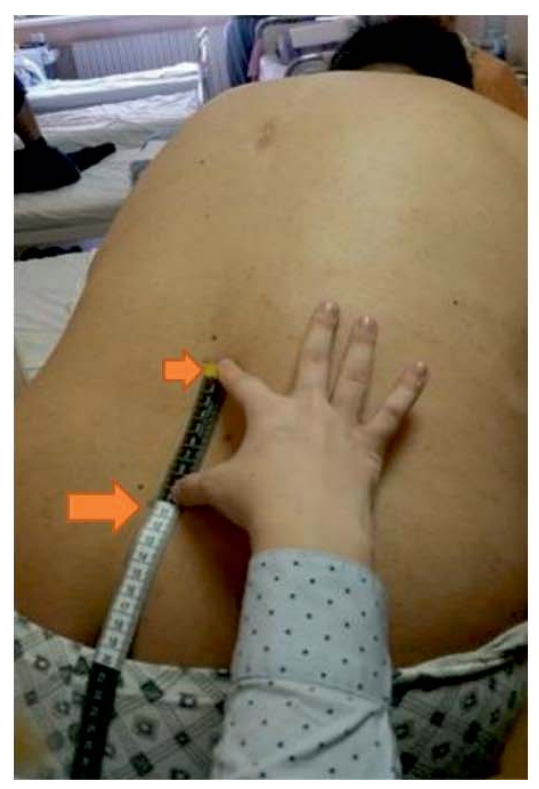

Figure 5. Schober's test.

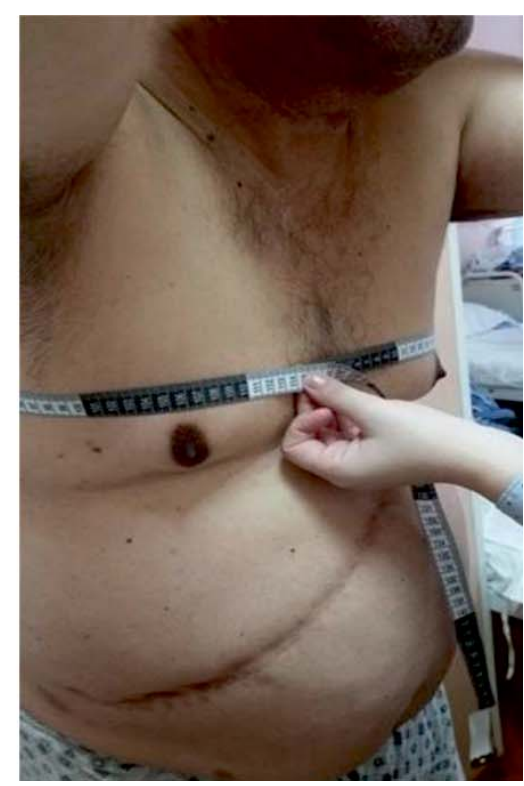

Figure 6. Chest expansion.

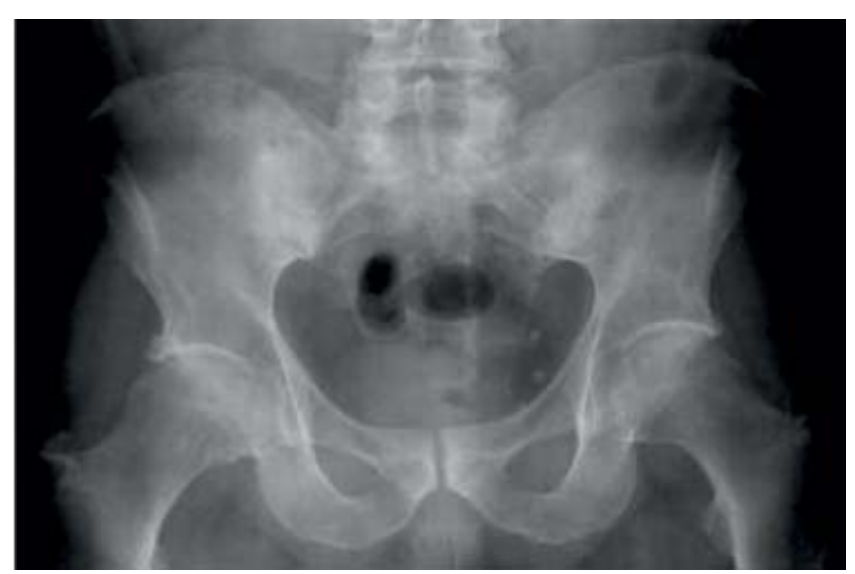

Figure 7. Grade 3-4 bilateral sacriliitis.

Laboratory findings revealed the following (after 14 months of treatment with Adalimumab):

$\mathrm{Hb}: 12.5 \mathrm{mg} / \mathrm{dL}$;

Ht: $38 \%$;

BUN: $42.42 \mathrm{mg} / \mathrm{dL}$;

serum creatinine level: $1.8 \mathrm{mg} / \mathrm{dL}$;

INR: 6.9;

ESR: $26 \mathrm{~mm} / \mathrm{h}$;

CRP: $1.8 \mathrm{mg} / \mathrm{L}$.

No anti-Adalimumab antibodies were detected

Paraclinical investigations showed a good response to Adalimumab. The patient was discharged and the continuation of treatment with Adalimumab and Sulfasalazine was recommended, along with antihypertensive, anticoagulant and anti-arrhythmic therapy.

\section{DISCUSSION}

The clinical picture of AS is initially dominated by persistent inflammatory lumbosacral pain, associated with restricted range of motion of the lumbar spine and later on by the limitation of the thoracic cavity expansion, along with imaging findings of sacroiliitis ${ }^{15}$.

AS can be diagnosed based on clinical, laboratory and imaging findings that are characteristic for axial spondylarthritis ${ }^{3}$. The first classification criteria for AS were debated in 1963, at the European Congress of Rheumatology in Rome ${ }^{16}$. In 1966, 2 elements (uveitis and thoracic pain) were removed from the criteria, because of low specificity and sensitivity. New York criteria were modified in 1984 (Table 2) by using inflammatory back pain components reported by Calin et $\mathrm{a}^{17}$.

The positive diagnosis of AS can be established if at least one clinical criteria (inflammatory back pain, limitation of lumbar spine or limitation of chest expansion) plus radiologic criteria (bilaterally grade 2 or unilateral grade 3-4 sacroiliitis) are fulfilled. These criteria have high specificity but low sensitivity, as they cannot be used for the early diagnosis of $\mathrm{AS}^{15}$. Both the restricted motion of the lumbar spine and the limitation of the thoracic cavity expansion are elements that are not initially present. Also, in the early stages of the disease, sacroiliitis may not be visible on the X-ray and it may take up to 9 years to be identified on pelvic $X$-ray. Therefore, in patients with early/pre-radiographic phase of AS, when there is clinical suspicion of sacroiliitis, 
Ankylosing Spondylitis: a Case Report

Table 1. Comparison of HLA-B27 distribution in Romanian patients with AS versus other European countries ${ }^{6}$

\begin{tabular}{|l|l|l|l|}
\hline Country & HLA-B27 positive (\%) & P-value & Reference \\
\hline Romania & 72.1 & & \\
\hline Bulgaria & 88 & 0.0005 & Minev et al. (1979) \\
\hline Hungary & 92.7 & 0.0001 & Gömör et al. (1977) \\
\hline Spain & 84.14 & 0.0018 & Collantes et al. (2007) \\
\hline Spain-Galicia & 94.3 & $<0.0001$ & Fernández-Sueiro et al. (2004) \\
\hline Germany & 82.2 & 0.02 & Rudwaleit et al. (2009) \\
\hline Norway (north) & 93 & $<0.0001$ & Bakland et al. (2005) \\
\hline United Kingdom & $90.2-94$ & $<0.0002$ & Brown et al. (1996), Freeston et al. (2007) \\
\hline Finland & 93 & $<0.0001$ & Jaakkola et al. (2006) \\
\hline
\end{tabular}

Table 2. Modified New York criteria for ankylosing spondylitis ${ }^{18}$

\begin{tabular}{|l|}
\hline Clinical criteria \\
\hline Low back pain for at least 3 months improved by exercise and not relieved by rest \\
\hline Limitation of lumbar spine motion in sagittal and frontal planes \\
\hline Chest expansion decreased relative to normal values for age and sex \\
\hline Radiological criteria \\
\hline Unilateral sacroiliitis grade $3-4$ \\
\hline Bilateral sacroiliitis grade 2-4 \\
\hline
\end{tabular}

computed tomography or magnetic resonance imaging of the sacroiliac joints should be obtained ${ }^{16}$.

Regarding the differential diagnosis of AS, the major entities that should be considered are lumbar strain or muscle spasm, which has an acute onset often with a precipitating event, herniated disc, with a clinical picture that is dominated by pain radiating below the knee, often associated with neurological deficits (numbness, tingling, weakness, absent or decreased deep tendon reflexes). Magnetic resonance imaging of the lumbar spine is helpful for the diagnosis. Osteoarthritis is another entity that should be taken into consideration. Compared to the pain from AS, which is inflammatory in nature, the pain from osteoarthritis worsens with activity and often does not associate inflammatory symptoms. Radiographic evaluation is suggestive for asymmetric joint-space narrowing, subchondral sclerosis and osteophytes. Other diseases that may mimic AS are rheumatoid arthritis, psoriatic arthritis, reactive arthritis, fibromyalgia, myalgia and diffuse idiopathic skeletal hyperostosis (DISH) $)^{3,19}$.

The main objectives of the management of patients with SpA are to improve short- and long-term healthrelated quality of life through relief of symptoms such as pain, stiffness and fatigue, maintenance of function, prevention of complications of spinal disease such as dorsal kyphosis, minimization of extraspinal and extraarticular manifestations and preservation/normalisa- tion of social participation ${ }^{20}$. The initial treatment for most patients with AS includes a series of nonpharmacologic (Table 3) measures and nonsteroidal antiinflammatory drug (NSAID) therapy.

In most patients diagnosed with axial $\mathrm{SpA}$ who are symptomatic, NSAIDs are recommended as initial therapy. The NSAIDs have been considered the cornerstone of pharmacologic intervention for AS since 1949, when phenylbutazone was available for use ${ }^{21}$. It takes about 1-2 weeks for an NSAID to reach an optimal effect, but sometimes a longer treatment period is required in order to determine the best drug option and the adequate dose. Once an NSAID has been determined to be effective within two to four weeks, then it is used on demand, according to symptoms; some patients require ongoing daily therapy to maintain the benefit ${ }^{20}$. In patients who have an inadequate response to initial therapy with two different NSAIDs used consecutively in an optimal dose for at least two to four weeks each, tumor necrosis factor (TNF)-alpha inhibitors represent the next line of treatment in patients with AS, any of them being an acceptable option ${ }^{21}(\mathrm{Ta}-$ ble 4).

The clinical response is usually rapid. The number needed to treat (NNT) in order to achieve a partial remission is estimated to be from 2.3 to $6^{22}$. However, some patients may experience an inadequate response (failure) to Infliximab therapy, which can be either 
Gabriela CEOBANU et al.

Table 3. Nonpharmacologic measures in patients with ankylosing spondylitis ${ }^{20}$

\begin{tabular}{|l|l|}
\hline \multicolumn{2}{|l|}{ Nonpharmacologic interventions } \\
\hline Patient education & $\begin{array}{l}\text { - education about the nature of their disease } \\
\text { - advice about the need for a lifelong exercise and posture-training program } \\
\text { - education about the importance of regular follow-up and management of comorbidities } \\
\text { - patients receiving pharmacologic treatment should be instructed about their medications }\end{array}$ \\
\hline Counseling regarding smoking cessation \\
\hline $\begin{array}{l}\text { Depression screening and } \\
\text { psychosocial support }\end{array}$ & $\begin{array}{l}\text { - screening for anxiety and depression } \\
\text { - patients should be encouraged to participate in patient support groups }\end{array}$ \\
\hline Physical therapy & $\begin{array}{l}\text { - exercises include postural training, range of motion exercises, stretching, recreational activities }+/- \\
\text { hydrotherapy. }\end{array}$ \\
\hline
\end{tabular}

Table 4. The typical doses of the TNF inhibitors used for treatment in $\mathrm{AS}^{20}$

\begin{tabular}{|l|l|}
\hline TNF inhibitor & Dosing \\
\hline Etanercept & $50 \mathrm{mg}$ weekly, administered as a subcutaneous injection of $50 \mathrm{mg}$ once a week or $25 \mathrm{mg}$ twice a week \\
\hline Infliximab & $\begin{array}{l}5 \mathrm{mg} / \mathrm{kg} \text { by intravenous infusion at zero, two, and six weeks followed by a maintenance dose of } 5 \mathrm{mg} / \\
\mathrm{kg} \text { every six to eight weeks }\end{array}$ \\
\hline Adalimumab & $40 \mathrm{mg}$ by subcutaneous injection every two weeks \\
\hline Golimumab & $50 \mathrm{mg}$ by subcutaneous injection every four weeks \\
\hline Certolizumab pegol & $\begin{array}{l}400 \mathrm{mg} \text { by subcutaneous injection at zero, two, and four weeks, followed by } 200 \text { mg every other week } \\
\text { or } 400 \mathrm{mg} \text { every four weeks }\end{array}$ \\
\hline
\end{tabular}

primary or secondary. Primary failure or lack of efficacy is characterized by the absence of any improvement after starting treatment with a TNF inhibitor and receiving therapy for at least 12 weeks. Secondary failure, or loss of efficacy, is characterized by an initial improvement with drug therapy, followed by relapse (worsening or recurrence of disease activity). Patients who do not tolerate the particular TNF (adverse events like rashes, injection site reactions etc.) are defined as experiencing a form of secondary drug failure. In case of inadequate response or intolerance to initial biologic agent, switching to a different biologic agent, such as another TNF inhibitor or an anti-IL-17 antibody is recommended. The frequency of good responses to TNF inhibitors is still substantial, but decreases with the use of subsequent agents, compared with the first use.

In our patient, after inadequate response to initial therapy with two different nonsteroidal anti-inflammatory drugs (Indomethacin and Diclofenac) and an immunomodulatory (Sulfasalazine), biologic therapy was initiated (Infliximab, $5 \mathrm{mg} / \mathrm{kg}$ iv at weeks 0 , 2 and 6 , and then every 6-8 weeks), while continuing therapy with Sulfasalazine. When the patient returned to the hospital for reevaluation, 5 months after the initiation of biologic therapy, the clinical examination showed improvement and the inflammatory markers were significantly decreased compared to previous values. However, 10 months later $(15$ months after the beginning of Infliximab therapy), the patient presented with worsening symptoms; high levels of inflammatory markers (ESR $20 \mathrm{~mm} / \mathrm{h}, \mathrm{CRP} 17.16 \mathrm{mg} / \mathrm{L}$ ) were noted and anti-Infliximab antibodies were detected. The inadequate response in this case falls into the second category: loss of efficacy or secondary failure to TNF inhibitor (secondary non-responder).

A common mechanism responsible for the development of secondary failure is immunogenicity due to the formation of antibodies against the TNF $\alpha$ antagonists. These antibodies interfere with the binding of TNF to its receptor. The presence of antibodies against TNF $\alpha$ antagonists will lead to lower serum drug levels and less duration of response. In a retrospective study, patients with loss of response to Infliximab with detectable antibodies were examined; change to another TNF $\alpha$ inhibitor was associated with a complete or partial response in $92 \%$ of patients, whereas increasing the dose led to only a $17 \%$ response $(\mathrm{P}<0.004)^{23}$. Patients with high titres of anti-drug antibodies (levels of antibodies against IFX $>9 \mu \mathrm{g} / \mathrm{mL}$ ) do not respond well to dose intensification of the same drug, but switching to a different agent pertaining to the same therapeutic class may restore the clinical response $(\mathrm{P}<0.03)^{24}$. In patients 
with low levels of antibodies, dose escalation is also an option; another approach to loss of response in patients with antibodies is to add an immunosuppressive agent. Concomitant use of immunomodulators, such as methotrexate, reduces the risk of antibody formation against $\mathrm{TNF} \alpha$ antagonist agents and improves clinical outcomes.

In our case, the patient was switched to a different anti-TNF $\alpha$ agent (Adalimumab, $40 \mathrm{mg}$ subcutaneously every two weeks), while continuing the administration of Sulfasalazine (500 mg x 5/day).

\section{CONCLUSIONS}

Ankylosing spondylitis is a chronic inflammatory arthritis characterized by periods of flares and remissions.

\section{References}

1. de Winter JJ, van Mens LJ, van der Heijde D, et al. Prevalence of peripheral and extra-articular disease in ankylosing spondylitis versus non-radiographic axial spondyloarthritis: a metaanalysis. Arthritis Res Ther. 2016;18:196.

2. van der Heijde $D$, Ramiro S, Landewé $R$, et al. 2016 update of the ASAS-EULAR management recommendations for axial spondyloarthritis. Annals of the Rheumatic Diseases. 2017;76(6):978991.

3. Yu DT, van Tubergen A. Diagnosis and differential diagnosis of axial spondyloarthritis (ankylosing spondylitis and nonradiographic axial spondyloarthritis) in adults, UpToDate, 2019. Available at https://www.uptodate.com/contents/diagnosisand-differential-diagnosis-of-axial-spondyloarthritis-ankylosing-spondylitis-and-nonradiographic-axial-spondyloarthritisin-adults? (accessed 14 Febr 2020).

4. Zhu W, He X, Cheng K, et al. Ankylosing spondylitis: etiology, pathogenesis, and treatments. Bone Research. 2019;7:22.

5. Reveille JD, Hirsch R, Dillon CF, et al. The prevalence of HLA-B27 in the US: data from the US National Health and Nutrition Examination Survey, 2009. Arthritis Rheum. 2012;64(5):1407-1411.

6. Popa OM, Bojinca M, Bojinca $V$, et al. Distribution of HLA-B27 in Romanian spondyloarthritides patients. International Journal of Immunogenetics. 2010;37(6):513-516.

7. Reveille JD, Weisman MH. The epidemiology of back pain, axial spondyloarthritis and HLA-B27 in the United States. Am J Med Sci. 2013;345(6):431-436.

8. de Blecourt J, Polman A, de Blecourt-Meindersma T. Hereditary factors in rheumatoid arthritis and ankylosing spondylitis. Ann Rheum Dis. 1961;20(3):215-220.

9. Reveille JD. The genetic basis of spondyloarthritis. Annals of the Rheumatic Diseases. 2011;70(1):44-50.

10. Reveille JD, Sims AM, Danoy P, et al. Australo-Anglo-American Spondyloarthritis Consortium (TASC). Genome-wide association study of ankylosing spondylitis identifies non-MHC susceptibility loci. Nature Genetics. 2010;42(2):123-127.

11. Taurog JD, Richardson JA, Croft JT, et al. The germfree state prevents development of gut and joint inflammatory disease in HLA-B27 transgenic rats. J. Exp. Med. 1994;180(6):2359-2364.

12. Rath $\mathrm{HC}$, Herfarth $\mathrm{HH}$, Ikeda JS, et al. Normal luminal bacteria, especially Bacteroides species, mediate chronic colitis,
The clinical case described presents a possible treatment complication that may arise in patients with AS. When a patient loses response to a TNF $\alpha$ antagonist, pharmacokinetic and immunogenic assessment with drug levels and antibodies should be performed, based on which the optimal choice of pharmacological therapy should be made.

Compliance with ethics requirements: "The authors declare no conflict of interest regarding this article". "The authors declare that all the procedures and experiments of this study respect the ethical standards in the Helsinki Declaration of 1975, as revised in 2008(5), as well as the national law. Informed consent was obtained from the patient included in the study"

gastritis, and arthritis in HLA-B27/human beta2 microglobulin transgenic rats. J. Clin. Invest. 1996;98(4):945-953.

13. Gooren LJ, Giltay EJ, van Schaardenburg D, et al. Gonadal and adrenal sex steroids in ankylosing spondylitis. Rheum. Dis. Clin. North Am. 2000;26(4):969-987.

14. Cai $G$, Wang $L$, Fan $D$, et al. Vitamin $D$ in ankylosing spondylitis: review and meta-analysis. Clin. Chim. Acta. 2015;438:316-322.

15. Ionescu $R$ (coord). Esentialul in reumatologie, Editura Medicala Amaltea 2006; 281-291.

16. Akgul O, Ozgocmen S. Classification criteria for spondyloarthropathies. World J Orthop. 2011;2(12):107-115

17. Calin A, Porta J, Fries JF, et al. Clinical history as a screening test for ankylosing spondylitis. JAMA. 1977;237(24):2613-2614

18. van der Linden S, Valkenburg HA, Cats A. Evaluation of diagnostic criteria for ankylosing spondylitis. A proposal for modification of the New York criteria. Arthritis Rheum. 1984;27(4):361368.

19. Patel P, Hussain H, Fahey J. Delayed diagnosis of ankylosing spondylitis: a missed opportunity? Cureus. 2019;11(9):e5723.

20. Yu DT, van Tubergen A. Treatment of axial spondyloarthritis (ankylosing spondylitis and nonradiographic axial spondyloarthritis) in adults, UpToDate, 2019. Available at https://www.uptodate.com/contents/treatment-of-axial-spondyloarthritis-ankylosing-spondylitis-and-nonradiographic-axial-spondyloarthritis-in-adults? (accessed 14 Febr 2020).

21 Baraliakos X, van den Berg R, Braun J, et al. Update of the literature review on treatment with biologics as a basis for the first update of the ASAS/EULAR management recommendations of ankylosing spondylitis. Rheumatology (Oxford). 2012;51(8):1378-1387.

22. Afif W, Loftus EV Jr, Faubion WA, et al. Clinical utility of measuring infliximab and human anti-chimeric antibody concentrations in patients with inflammatory bowel disease. Am J Gastroenterol. 2010;105(5):1133-1139.

23. Paul S, Moreau AC, Del Tedesco E, et al. Pharmacokinetics of adalimumab in inflammatory bowel diseases: a systematic review and meta-analysis. Inflamm Bowel Dis. 2014;20(7):12881295. 
